\title{
The ISO 9001 International Standards in a System of the Banking Services Quality Management
}

\author{
Yu. M. Demkiv
}

Financial analyst-legal counsel, LTD “Paritet-Yuh”, Odessa, Ukraine

\begin{abstract}
The aim of the article is to test the hypothesis of a positive financial effect from ISO 9001 quality standards introduction by commercial banks in Ukraine. The article is devoted to testing the hypothesis about the impact of banking services quality standards on the efficiency of banking activities. An example of the Ukrainian banks an empirical study for the period 2008-2017 was conducted. The efficiency of banking activity was estimated by means of the stochastic frontier analysis taking into account parameters of income, expenses and other parameters of banking activity. The results of econometric modeling confirmed the positive effect of the introduction by commercial banks of the standards of quality of the ISO 9001 group on the efficiency of their activities. At the present stage of development, commercial banks of Ukraine demonstrate trends in the spread of adaptation of their management systems to international requirements and the introduction of international quality standards into their own activities. The results of the conducted research proved that the successful completion of the certification procedure of the bank's quality management system not only plays a significant role in terms of forming a positive image of the bank in the banking services market but also creates significant prospects for increasing the efficiency of its operations. Thus, the analysis of the averaged parameters of the activities of certified banks and banks that do not have a certificate of compliance with international standards has shown that commercial banks whose quality management system is appropriate to the international standards are usually characterized by better indicators of financial sustainability and profitability of their activities. On the other hand, the results of econometric modeling of the impact of the certification procedure on the efficiency of banking activities have shown that the presence of a certificate in the bank creates additional efficiency of its activities. Thus, the hypothesis regarding the presence of a positive financial effect of the quality standards of the ISO 9001 group has been confirmed. Given the multidimensional orientation of the requirements of ISO 9001 standards for quality management systems of banking institutions, the research in the direction of analyzing the achievement of the goals set by the provisions of these standards and estimation of their interconnections with the input and output parameters of the functioning of banking subsystems is promising.
\end{abstract}

Keywords: standards of ISO 9001, efficiency, commercial banks, quality of banking services, banking management.

\section{JEL Classification: G21, L15, M21.}

(C) The Author, 2018. This article is published with open access at Sumy State University.

\section{The problem statement in a general form}

The quality management of banking services, aimed at ensuring compliance of the banks' offer with the expectations of customers, involves the formation of the strategy and tactics of quality management, as well as the development and implementation of specific measures to improve it. At the same time, the quality management must coincide with the general strategy of the bank development and correspond to market trends in the development of banking business, which requires the formation of a set of principles, which are the basis for managerial actions. At the international level, the basic principles and requirements for a quality management system are set out in the form of the ISO 9001 standard, which at the present stage is actively implemented by the banks in different countries of the world. The International Organization for Standardization notes that the introduction of ISO 9001 standards is typical for the quality management systems that are oriented towards building an organization's ability to meet the needs and expectations of its customers. Herewith, the customer requirements are an input factor for the development of a quality management system, and the customer satisfaction is seen as a performance indicator of the system. At the same time, the financial aspect is generally not considered as the main objective of the bank certification in accordance with international quality standards, taking into account the absence of the direct causal relationships. 


\section{The analysis of the recent research and publications}

In recent years, the number of studies on the problems, perspectives and consequences of the organizations' certification in accordance with the requirements of the international standards of the ISO 9001 group has been increasing in the scientific literature. In particular, F. Francheskini, M. Galetto, P. Cecconi (2006) studied the issues of the adaptation and dissemination of standards in various sectors of the world economy. Let us also note the work of A. Yahia-Berrouiguet, I. Mankouri, N. Benarbia (2015) in order to systematize and rank the company's profits from passing the ISO 9001 certification. At the same time, the positive impact of the companies' certification in the real sector on their overall financial status has been empirically confirmed in the works of C. Chow-Chua, M. Goh, T. B. Wan (2003), D. S. Sharma (2005), A. Terlaak, A. A. King (2006), B. Manders (2015). At the level of the banking sector, we can note the work of N. Hreniuc on the systematization of the main parameters of the functioning of the quality management system in accordance with the requirements of the ISO 9001 standards.

\section{The selection of the previously unresolved issues}

It should be noted that in the modern scientific literature there is, in fact, no scientific research aimed at revealing the results, including the financial benefits, as a result of the introduction of international quality standards directly at the level of banking institutions. Taking into account the existing tendencies towards the introduction of the ISO 9001 standards by the banks and other financial institutions, the aspect of the empirical study of the financial effect of passing through the certification procedure by commercial banks becomes a scientific actuality and practical significance.

\section{The main material and the results of the study}

In Ukraine, the introduction of the ISO 9001 standards by the banking institutions begins with the receipt by the PJSC "CREDYTPROMBANK" of the certificate of the compliance of the bank quality management system with the requirements of the ISO 9001:2000 standard in 2005. The certification extended to the field of banking services, covering the management processes, customer service, technologies and regulatory documents. In 2008, the bank received the second issue of the certificate valid until 2011 (System of quality, PAT "KREDYTPROMBANK").

In 2009, two Ukrainian banks received the certificates of compliance of the management system with the ISO 9001:2008 quality standard. The JSC "Ukreximbank" successfully passed a supervisory audit five times in succession to confirm the compliance of the quality management system with the requirements of the standard up to and including 2013 (AT Ukreximbank annual report, 2013). The JSC "PERSHYI INVESTYTSIINYI BANK" made the first steps towards the beginning of the process of certification of the business processes under the ISO 9001:2000 quality assessment programme in 2008, however, only in 2009 the bank received the ISO 9001:2008 quality certificate. The results of the supervisory audit in 2010-2011 confirmed the compliance of the quality management system with the requirements. In 2012 the JSC "PERSHYI INVESTYTSIINYI BANK" received the ISO 9001:2008 certificate for the next three years of its operation as a result of the recertification audit of the quality management system (History of bank, AT "PERSHYI INVESTYTSIINYI BANK”).

The PJSC "CREDIT AGRICOLE BANK" joined the list of the banks, the management system of which meets the international requirements, in 2011, having received the certificate of compliance with the ISO 9001:2008 standard in the direction of the automobile lending. In the period up to 2017 , the bank confirmed the compliance of the quality management system with the requirements of the standard on the results of the annual audit, and based on the results of the recertification audit conducted in July 2017, the bank received the confirmation of the compliance of the quality management system with the version of the ISO 9001:2015 standard and obtained the corresponding certificate (Press-center, PAT "Credit Agricole bank").

In 2018 PJSC "BANK AVANHARD" successfully passed the quality management system audit regarding the compliance with the international requirements and received the ISO 9001:2015 certificate in the direction of "Services in the field of transactional business, money market, foreign exchange market, debt securities market, digital banking" (Bank AVANHARD, certified by international standards ISO 9001:2015 and ISO 27001:2013). Thus, it can be noted that in the banking system of Ukraine there is a gradual transition of the banks to building the quality management systems in accordance with the requirements of the international standards.

It should be noted positively that there is a differentiation of the banking activities, according to which the international certificates of quality have been received by the Ukrainian banks. On the other hand, it is 
ambiguous that from the five banks that received certificates of compliance with the ISO 9001 quality standards in different periods of time, only two have currently a valid confirmation of the certificates' continuation. All this updates the need to study the role of having a certificate of quality for the results of the bank, which will help to understand the reasons that determine the trends of the certification of banking institutions.

That is why, taking into account the results of foreign studies on the formation of additional efficiency of the companies in the real sector, obtained as a result of the presence of the certificate of compliance with the ISO 9001 quality international standards, we can put forward a hypothesis about the positive impact of the certification of the quality management system of the bank on its efficiency.

For the study, a sample of 10 Ukrainian banks was formed, four of which had a verified certificate of the compliance with the ISO 9001 quality standard, and six banks were selected from different groups that are market makers in the banking market. The study period covers the years of 2008-2017, which allows you to cover the years of availability of the quality standard in at least one of the selected banks.

The efficiency of the bank was selected to be an effective variable of the study. To calculate this indicator we use an approach to determining the efficiency of the banking business, which was proposed and successfully tested in the study of A.V. Buriak (2012). In accordance with this approach, the effectiveness of the banking business can be assessed on the basis of the following list of input factors:

$>$ parameters characterizing the expenses of the bank - the value of the general administrative expenses per unit of the generated income, the value of personnel costs per unit of the generated income;

$>$ parameters characterizing the bank's income - net interest margin, net non-interest margin;

additional parameters - net spread, the share of the negatively classified loans in the structure of the loan portfolio of the bank, the share of the bank assets in the banking system.

The analysis of the available statistical data on the individual parameters characterizing the components of the efficiency of the banking activities has shown that, on average, there are differences in the indicators for banks that have implemented measures for the certification of the quality management systems and for other banks in the sample. Thus, Figure 1 shows the difference in the cost parameters for two types of the bank. It should be noted that according to the general administrative expenses indicator, there is no clear tendency of the indicator both in time and in the context of different groups.

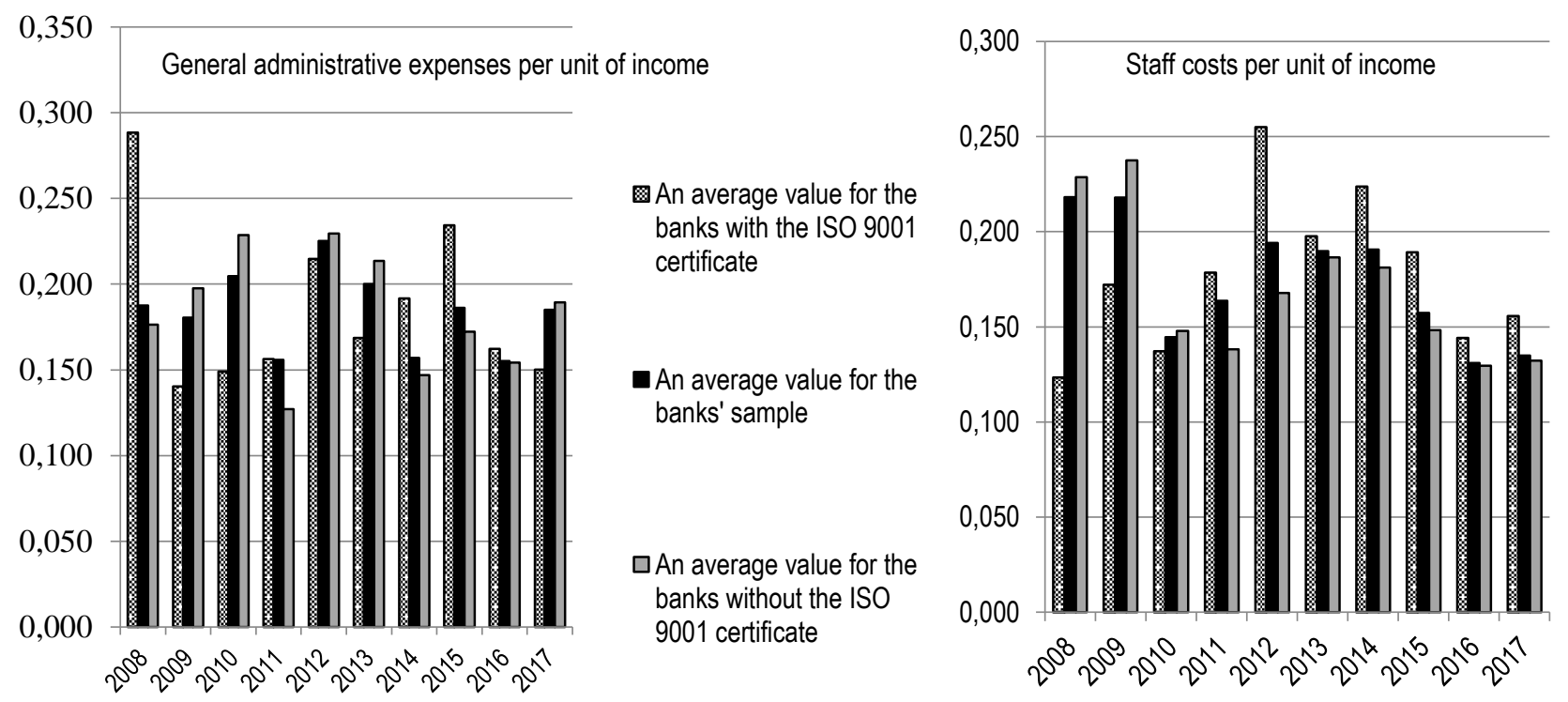

Figure 1. A statistical description of the parameters characterizing the expenses of the banks of different types for the period of 2008-2017, cop. for 1 UAH of income (built by the author according to the data (Indicators of banking system, 2018))

On the other hand, according to the indicator of the relative personnel costs in most of the periods, there is an excess of the average for banks with valid certificates of quality management systems in comparison with other banks, taking into account the fact that the measures to improve such a system must necessarily include the staff training. At the same time, the attention should be drawn to the fact that the cost indicators do not show the long-term trends in the change of their average values, which indicates the existence of a certain level optimal in terms of management of the bank, sufficient to ensure its effective functioning. 
Analyzing the indicators, which characterize the banks' income (Figure 2), we note that according to the net interest margin indicator over the majority of periods, there is the excess of the indicator for the banks that did not pass the certification procedure for the quality management systems compared to the certified banks, but during the 2016-2017 there is a typical opposite trend with a significant rupture of the averaged values.
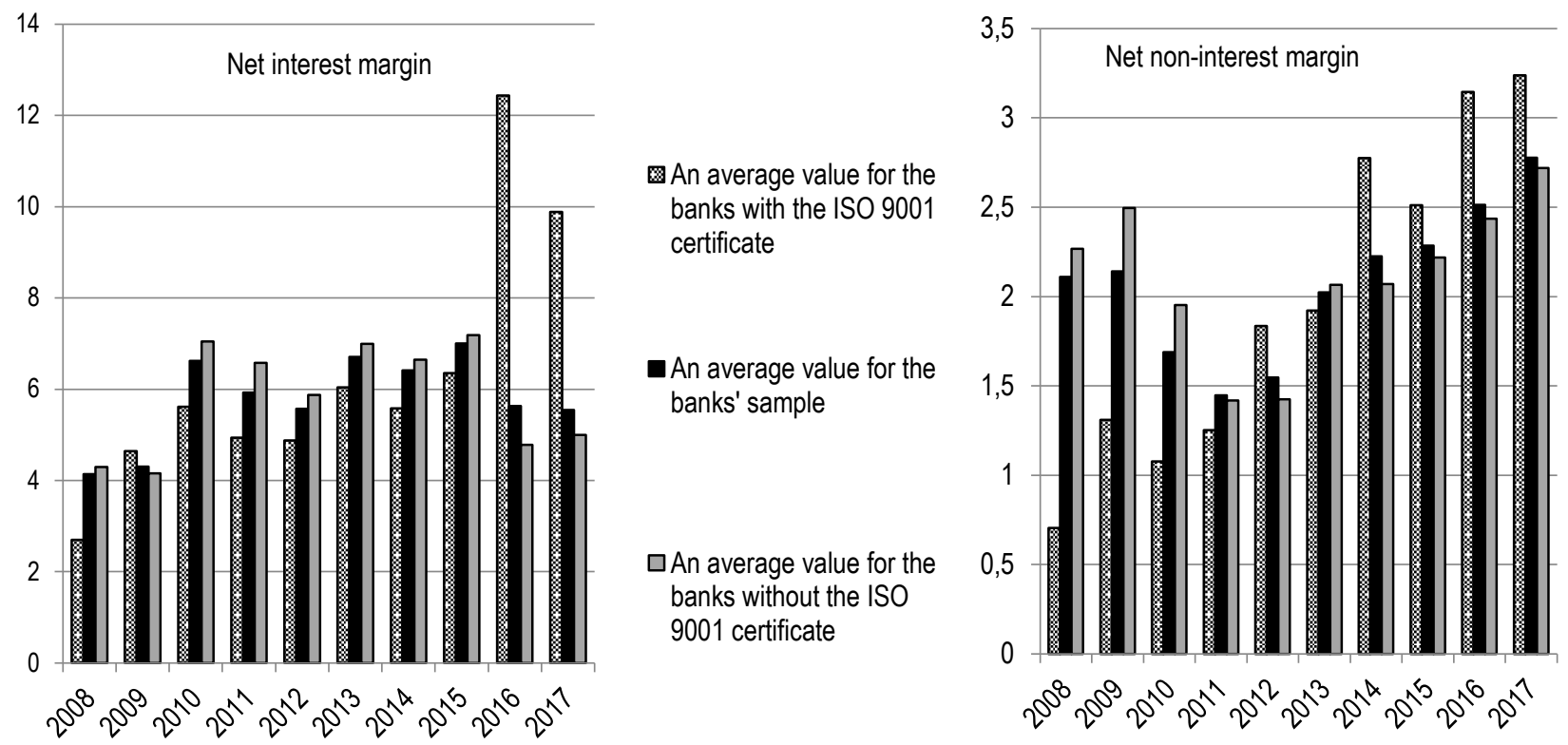

Figure 2. A statistical description of the parameters characterizing the income of the banks of different types for the period of 2008-2017,\% (built by the author according to the data (Indicators of banking system, 2018))

In turn, the parameter of the net non-interest margin is characterized by the excess of the values obtained for certified banks over other banks of the sample starting from 2012 with a gradual build-up of the gaps in subsequent periods. Thus, the analysis of the averaged statistical data on the parameters of the income and expenses showed the ambiguity of the identified trends that would characterize the efficiency of the functioning of the banks that have successfully passed the certification procedure of the quality management systems.

The attention is also drawn to the fact that among the additional parameters of the bank efficiency for certified banks, the receipt of the lower average values of the net spread compared to other banks (Figure 3) is a characteristic feature. At the same time, the average level of the share of negatively classified loans for the banks whose quality management system meets international standards is significantly lower than the indicator calculated for other banks in the sample, which positively characterizes the impact of the management measures regarding the standardization on the financial stability of the banks.
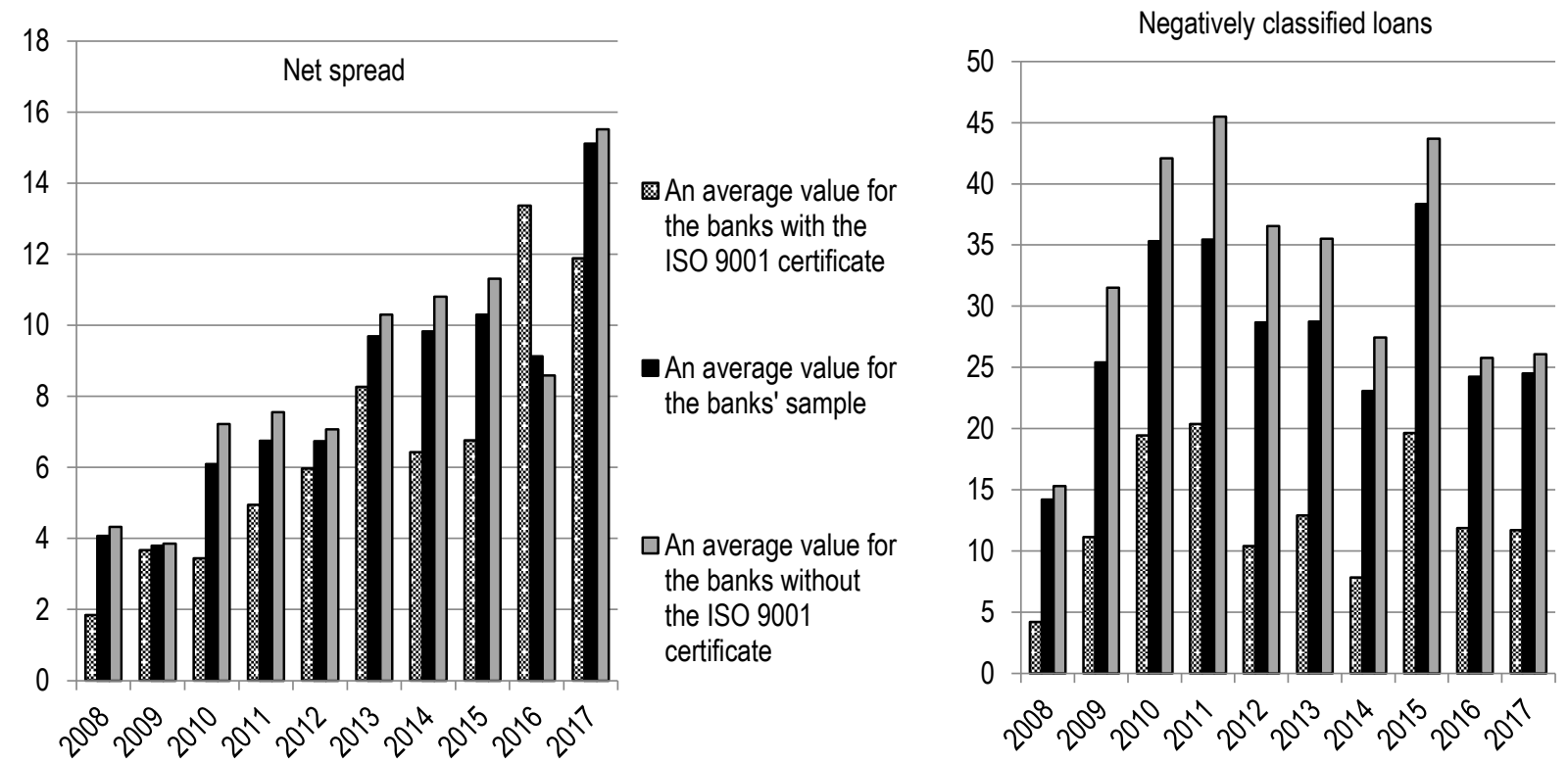

Figure 3. A statistical description of the additional parameters of the efficiency of the banks of different types for the period of 2008-2017,\% (built by the author according to the data (Indicators of banking system, 2018)) 
It should be noted that according to the scope of the bank's activity indicator, which is based on the calculation of the size of assets, the certified banks are characterized by significantly lower indicators of their activities compared to other banks of the sample (Figure 4). This fact indicates that the trends in the implementation of the international standards are characteristic not only for leading banks by the scope of activity but can also be the result of the bank's selection of the quality management strategy and its focus on a long-term effectiveness.

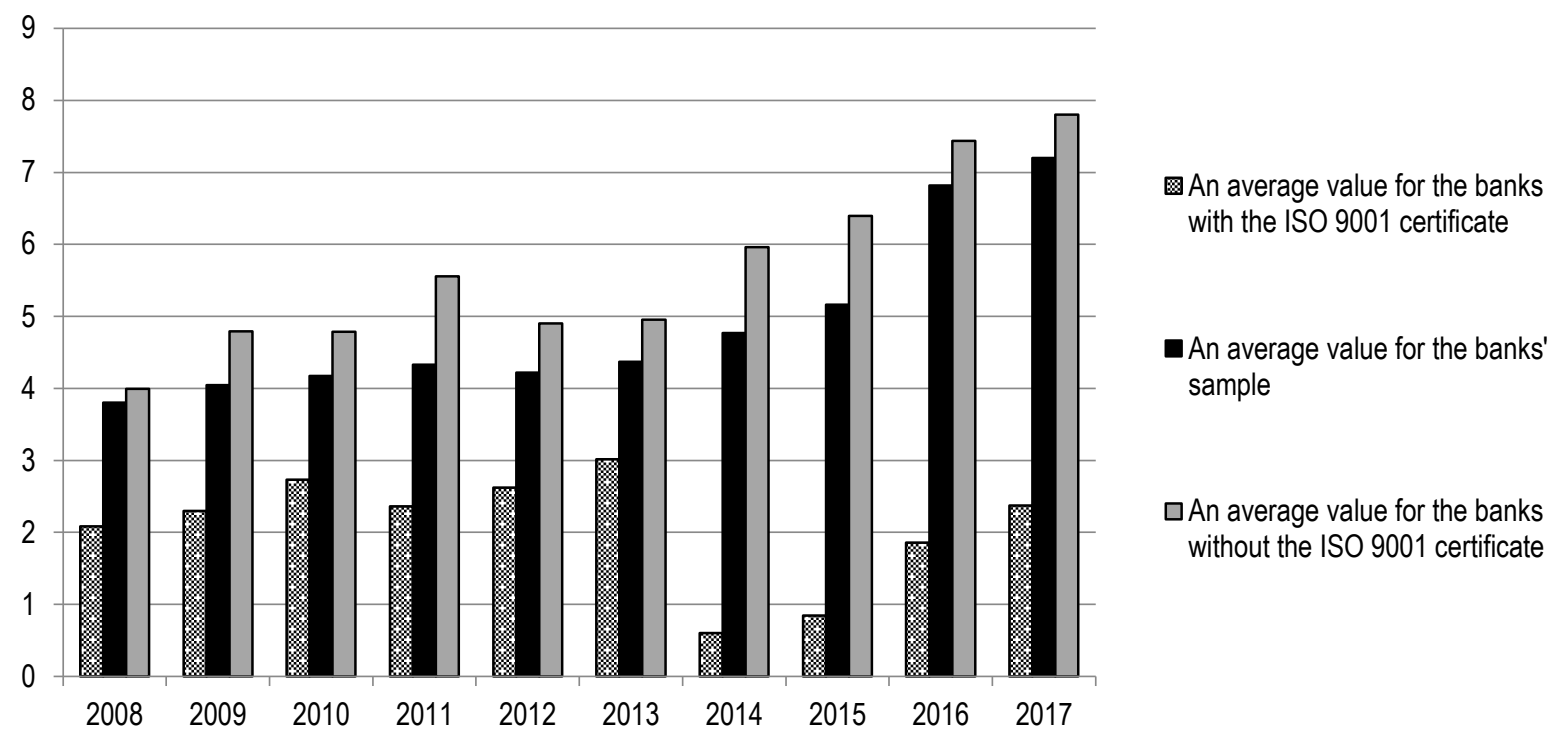

Figure 4. The statistical data describing the share of the assets of selected banks of different types in the banking system of Ukraine for the period of 2008-2017,\% (built by the author according to the data (Indicators of banking system, 2018))

To assess the efficiency of the banks, the stochastic frontier analysis method is used, which also involves the definition of the output variable, which is influenced by the input parameters. The effective variable used to determine the efficiency of the banks is the return on assets of the banks, calculated as the ratio of the profit before the taxation to the bank's total assets, determined in percentages. As we see in Fig. 5 the average return on assets of the certified banks was significantly higher than that of other banks in the sample during all investigated periods (during the unprofitable for all banks years, the level of losses of the banks that had the confirmation of the compliance of quality management systems with the requirements of the standard was lower compared to other banks).

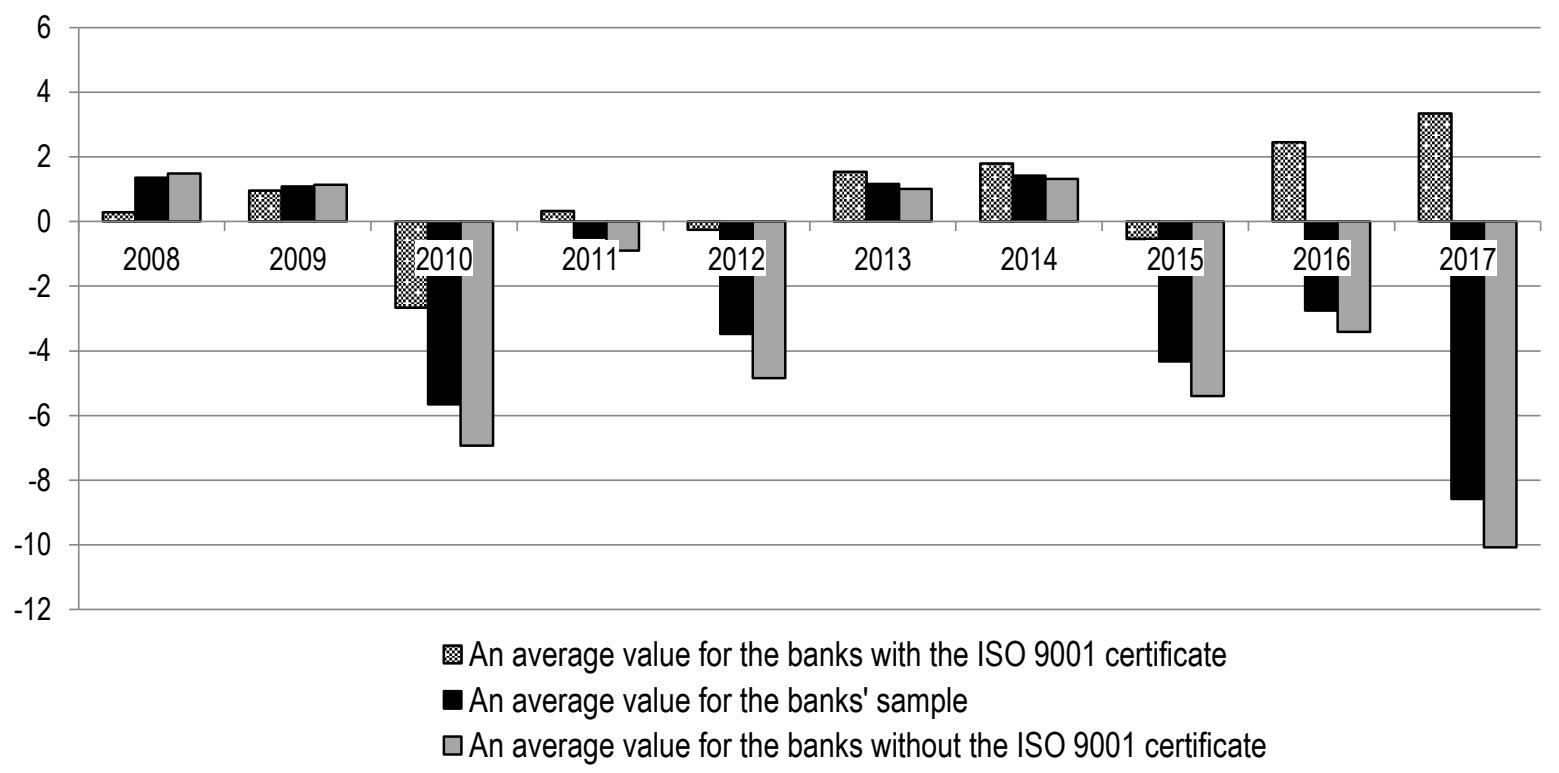

Figure 5. The statistical data describing the return on assets of the sample of the banks of different types for the period of 2008-2017,\% (built by the author according to the data (Indicators of banking system, 2018))

Thus, the preliminary analysis has shown that in general, the banks' efforts aimed at ensuring the compliance of the quality management systems with the requirements of international standards do not have a significant 
effect concerning the provision of additional income, but they play a significant role in maintaining the financial sustainability and profitability of their activities.

The chosen method of the econometric analysis involves the logarithm of the data. Taking into account the fact that the estimated return on assets of the banks in the sample also took negative values, before carrying out the logarithm of the model variables, the normalization of the return on assets was made by adding the absolute level of the smallest negative value of the indicator to all observations of the indicator in the sample.

At the same time, the final conclusions on the confirmation or refutation of the hypothesis can be formulated only by the results of the econometric modeling. So, at the first stage, we will evaluate the efficiency of the formed banks' sample on the basis of stochastic frontier analysis by means of the Stata $12 \mathrm{SE}$ software. It should be noted that this toolkit provides four specifications of the stochastic frontier analysis model. To select the specification, let us compare the parameters of the adequacy of the constructed models (Table 1).

Taking into account the criteria of adequacy, it is advisable to choose for the estimation the model with the change of time based on the function of expenditures. The peculiarity of this specification is, on the one hand, the assumption of the existence of invariant unchanged factors that are not included in the sample but affect the result, and, on the other hand, the consideration of an unlimited number of the input factors (Belotti, F., Daidone, S., Ilardi ,G., \& Atella V., 2013).

Table 1. The adequacy criteria of various specifications of the estimation model of the commercial banks' efficiency (author's calculations)

\begin{tabular}{|l|c|c|}
\hline Model function & Production function & Cost function \\
\hline \multirow{2}{*}{ Time-invariant model } & Wald chi2(7) $=50,03$ & Wald chi2(7) $=50,03$ \\
& Prob $>$ chi2 $=0,0000$ & Prob $>$ chi2 $=0,0000$ \\
& Log likelihood $=-128.81166$ & Log likelihood $=-128,81166$ \\
\hline \multirow{2}{*}{ Time-varying decay model } & Wald chi2 $(7)=20,01$ & Wald chi2(7) $=124,24$ \\
& Prob $>$ chi2 $=0,0055$ & Prob $>$ chi2 $=0,0000$ \\
& Log likelihood $=74,083698$ & Log likelihood $=-116,0735$ \\
\hline
\end{tabular}

Taking into account the list of the input and output parameters, the constructed econometric model for estimating the panel data has the following form:

$\ln R O A_{i t}=\beta_{0}+\sum_{j=1}^{7} \beta_{j} \ln x_{j i t}+v_{i t}+u_{i t}$

where $R O A_{i t}$ - the return on assets of the $i$-th bank in the $t$ period;

$x_{j i t}-\mathrm{j}$-th factor variable for the $i$-th bank in the $t$ period;

$v_{i t}$ - a measurement and specification error;

$u_{i t}$ - the value of the inefficiency of the $i$-th bank in the $t$ period.

The results of the evaluation of factors that determine the efficiency of the Ukrainian commercial banks are presented in Table 2. Analyzing the results of the calculations, we note that the statistically significant coefficients of impact were obtained for five parameters out of seven factor indicators. Thus, the factors stimulating the efficiency of the bank's operation can be considered such indicators as personnel costs, net interest margin and the proportion of the bank assets, which is quite natural, taking into account the investment nature of the human capital as the organization cost items, the existence of a direct link between the formation of interest income and the bank profit, as well as a significant role of the scale effect in ensuring the profitability of the banking activities. On the other hand, the results appeared to be unexpected concerning the existence of the inverse relationship between such parameters as net non-interest margin and net spread on the bank's efficiency, which may be the result of the insufficient profitability of certain groups of assets and liabilities of the bank and, as a result, the formation of low values of the obtained indicators with the reverse trends of their dynamics relative to other parameters.

At the same time, let us note that the parameters of the general administrative expenses and negatively classified loans have a negative sign in the calculated coefficients, which, despite the statistical insignificance, indicates the available potential of the disabling effect of these factors in the formation of the bank efficiency.

The results of calculations of the impact of individual parameters on the efficiency of banks are presented for the sample as a whole. At the same time, the purpose of the study also involves conducting calculations taking into account the efficiency of the individual banks. 
Table 2. The results of assessing the efficiency of the banks and the impact of factors that determine it (author's calculations)

\begin{tabular}{|c|c|c|c|c|c|c|}
\hline Factor sign & Coefficient & Standard error & $\mathbf{z}$ & $\mathbf{P}>|\mathbf{z}|$ & Lower $95 \%$ & Upper 95\% \\
\hline General administrative expenses & $-0,070$ & 0,195 & $-0,36$ & 0,719 & $-0,452$ & 0,312 \\
\hline Staff costs & 1,396 & 0,297 & 4,70 & 0,000 & 0,814 & 1,979 \\
\hline Net interest margin & 2,609 & 0,290 & 8,99 & 0,000 & 2,040 & 3,178 \\
\hline Net non-interest margin & $-0,381$ & $-0,209$ & 1,82 & 0,068 & $-0,792$ & 0,028 \\
\hline Net spread & $-1,676$ & 0,216 & $-7,76$ & 0,000 & $-2,099$ & $-1,252$ \\
\hline Negatively classified loans & $-0,114$ & 0,113 & $-1,01$ & 0,312 & $-0,337$ & 0,107 \\
\hline Share of the bank assets & 0,303 & 0,113 & 2,67 & 0,008 & 0,080 & 0,526 \\
\hline Constant & 5,091 & 0,679 & 7,49 & 0,000 & 3,759 & 6,423 \\
\hline \multicolumn{7}{|c|}{ Model parameters } \\
\hline $\mathrm{mu}$ & $-188,286$ & 2809,628 & $-0,07$ & 0,947 & $-5695,055$ & 5318,483 \\
\hline eta & $-0,324$ & 0,076 & $-4,22$ & 0,000 & $-0,474$ & $-0,173$ \\
\hline $\operatorname{lnsigma~}^{2}$ & 5,778 & 14,637 & 0,39 & 0,693 & $-22,911$ & 34,468 \\
\hline ilgtgamma & 6,449 & 14,663 & 0,44 & 0,660 & $-22,291$ & 35,190 \\
\hline sigma $^{2}$ & 323,362 & 4733,36 & & & $1,12 \mathrm{e}-10$ & $9,32 \mathrm{e}+14$ \\
\hline gamma & 0,998 & 0,023 & & & $2,08 \mathrm{e}-10$ & 1 \\
\hline sigma_u ${ }^{2}$ & 322,852 & 4733,361 & & & $-8954,365$ & 9600,069 \\
\hline sigma_v ${ }^{2}$ & 0,510 & 0,078 & & & 0,356 & 0,664 \\
\hline
\end{tabular}

The estimated values of the efficiency for the sample of banks is shown in Table 3.

Table 3. The results of assessing the efficiency of the Ukrainian banks for the period of 2008-2017 (author's calculations)

\begin{tabular}{|l|c|c|c|c|c|c|c|c|c|c|}
\hline \multicolumn{1}{|c|}{ Name of the bank } & $\mathbf{2 0 0 8}$ & $\mathbf{2 0 0 9}$ & $\mathbf{2 0 1 0}$ & $\mathbf{2 0 1 1}$ & $\mathbf{2 0 1 2}$ & $\mathbf{2 0 1 3}$ & $\mathbf{2 0 1 4}$ & $\mathbf{2 0 1 5}$ & $\mathbf{2 0 1 6}$ & $\mathbf{2 0 1 7}$ \\
\hline JSC "Ukreximbank" & 1,27 & 1,39 & 1,58 & 1,88 & 2,40 & 3,37 & 5,40 & 10,41 & 26,02 & 93,85 \\
\hline JSC “OSCHADBANK" & 1,15 & 1,21 & 1,31 & 1,45 & 1,68 & 2,05 & 2,71 & 4,02 & 6,96 & 15,16 \\
\hline PJSC CB "PRIVATBANK" & 1,01 & 1,02 & 1,02 & 1,03 & 1,04 & 1,06 & 1,09 & 1,13 & 1,18 & 1,27 \\
\hline PJSC "CREDIT AGRICOLE BANK" & 1,03 & 1,04 & 1,06 & 1,08 & 1,11 & 1,16 & 1,22 & 1,33 & 1,50 & 1,78 \\
\hline JSC "PERSHYI INVESTYTSIINYI BANK" & 1,12 & 1,17 & 1,24 & 1,35 & 1,52 & 1,78 & 2,23 & 3,07 & 4,80 & 9,04 \\
\hline JSC "Raiffeisen Bank Aval" & 1,03 & 1,04 & 1,06 & 1,08 & 1,12 & 1,17 & 1,24 & 1,36 & 1,54 & 1,86 \\
\hline JSB “UKRGASBANK" & 1,29 & 1,42 & 1,63 & 1,96 & 2,54 & 3,64 & 6,00 & 12,02 & 31,73 & 123,4 \\
\hline JSC "UkrSibbank" & 1,02 & 1,03 & 1,05 & 1,07 & 1,09 & 1,13 & 1,19 & 1,28 & 1,42 & 1,66 \\
\hline PJSC “ALFA-BANK" & 1,06 & 1,09 & 1,12 & 1,17 & 1,25 & 1,37 & 1,55 & 1,84 & 2,37 & 3,40 \\
\hline PJSC "CREDYTPROMBANK" & 1,04 & 1,06 & 1,09 & 1,12 & 1,18 & 1,26 & - & - & - & - \\
\hline
\end{tabular}

You can note the tendency from the table for a permanent increase in the efficiency during the study period for the entire sample of the banks. At the same time, the purpose of the study is to verify the existence of the impact of the banks' certification on the efficiency of their activities. The Difference-in-Differences model, based on the formation of a sample of two groups of research objects, was selected for the evaluation. The first group (under study) is subject to certain factors (in our case, undergoes a certification procedure) during the study period. The second group (control) does not fall under the impact of this factor during the study period. The comparison of the estimates of the average change in the efficiency indicator during the duration of the factor and before its occurrence for the two groups of factors allows to estimate the impact of this factor on the efficiency indicator. Thus, the model allows to eliminate the impact of permanent differences in the parameters of objects belonging to different groups under study, as well as to level the impact of the time factor on the change of the efficiency indicator. The econometric model has the following form:

$E f f=\beta_{0}+\beta_{1} d B+\delta_{0} d 2+\delta_{1} d 2 \cdot d B+u$

where Eff - an effective variable indicating the efficiency of the banking activity;

$d 2$ - a fictitious variable, indicating the period of the impact of the factor indicator - the certification of the quality management of banking services;

$\delta_{0}$ - the coefficient that takes into account the impact of the parameters that would cause a change in the efficiency indicator in the absence of a factor of the certification impact;

$d B$ - a fictitious variable denoting the group under study - banks that have received the certificates of compliance with the quality standards; 
$\beta_{1}-$ the coefficient that takes into account the differences between the group under study and the control group prior to the beginning of certification procedures;

$d 2 \cdot d B$ - a fictitious variable of the interaction of the group under study and the period of the factor impact; $\delta_{1}$ - the coefficient of the impact of certification of the quality management systems on the efficiency of the banking activity;

$u$ - a measurement and specification error.

The results of the calculations for identifying the role of the certificate concerning the compliance of the quality management system of banks to the requirements of the international standards of the ISO 9001 group in ensuring the efficiency of the banking activity is shown in Table 4.

Table 4. The results of assessing the impact of the banking services certification on the bank's efficiency (author's calculations)

\begin{tabular}{|c|c|c|c|c|}
\hline Parameter & Efficiency & Standard error & $|\mathbf{t}|$ & $\mathbf{P}>|\mathbf{t}|$ \\
\hline \multicolumn{5}{|c|}{ Before passing the certification procedure } \\
\hline Control group & 1,095 & & & \\
\hline Experimental group & 1,102 & & & \\
\hline Difference & 0,008 & 0,005 & 1,58 & 0,099 \\
\hline \multicolumn{5}{|c|}{ After passing the certification procedure } \\
\hline Control group & 4,970 & & & \\
\hline Experimental group & 6,079 & & & \\
\hline Difference & 1,110 & 0,352 & 1,87 & 0,076 \\
\hline$\delta 1$ & 1,102 & 0,171 & 2,61 & 0,009 \\
\hline
\end{tabular}

Analyzing the results of the evaluation, we should note that the differences in the values of the banking performance for the group under study and the control group of banks were observed at all stages of the study. At the same time, the rupture of values significantly increases while analyzing the parameters of the efficiency of certified banks in the period after they have passed the procedure of confirming the compliance of the quality management system with the requirements of the international standards. Thus, we can conclude on the confirmation of the hypothesis previously put forward about the existence of a positive impact of the certification of banking business on the financial parameters of its activities.

\section{Conclusions}

At the present stage of development, commercial banks of Ukraine demonstrate trends in the spread of adaptation of their management systems to international requirements and the introduction of international quality standards into their own activities. The results of the conducted research proved that the successful completion of the certification procedure of the bank's quality management system not only plays a significant role in terms of forming a positive image of the bank in the banking services market but also creates significant prospects for increasing the efficiency of its operations. Thus, the analysis of the averaged parameters of the activities of certified banks and banks that do not have a certificate of compliance with international standards has shown that commercial banks whose quality management system is appropriate to the international standards are usually characterized by better indicators of financial sustainability and profitability of their activities. On the other hand, the results of econometric modeling of the impact of the certification procedure on the efficiency of banking activities have shown that the presence of a certificate in the bank creates additional efficiency of its activities. Thus, the hypothesis regarding the presence of a positive financial effect of the quality standards of the ISO 9001 group has been confirmed. Given the multidimensional orientation of the requirements of ISO 9001 standards for quality management systems of banking institutions, the research in the direction of analyzing the achievement of the goals set by the provisions of these standards and estimation of their interconnections with the input and output parameters of the functioning of banking subsystems is promising.

\section{References}

1. BANK AVANHARD sertyfikovano za standartamy ISO 9001:2015 ta ISO 27001:2013 [Bank AVANHARD is sertified by international standards ISO 9001:2015 and ISO 27001:2013]. Bureau Veritas Ukraine. Retrieved from: http://www.bureauveritas.com.ua/home/news/certification-avangard-bank-iso9001-iso-27001?presentationtemplate=bv_master_v2/news_full_story_presentation_press_releases_v2.

2. Belotti, F., Daidone, S., Ilardi ,G., \& Atella V. (2013). Stochastic frontier analysis using Stata. The Stata Journal, 13(4), 719-758. 
3. Buriak, A. V. (2012). Upravlinnia efektyvnistiu bankivskoho biznesu [Management of efficiency of banking business]. Candidate's thesis. Sumy: UABS NBU.

4. Chow-Chua, C., Goh, M., \& Wan T. B. (2003). Does ISO 9000 Certification Improve Business Performance? International Journal of Quality \& Reliability Management, 20(8), 936-53.

5. Francheskini, F., Galetto, M., \& Cecconi, P. (2006). A worldwide analysis of ISO 9000 standard diffusion. Benchmarking: An International Journal, 13(4), 523-541.

6. Hreniuc, N. Coordinates of Banking Services Quality Management. Retrieved from: ftp://ftp.repec.org/opt/ReDIF/RePEc/rau/homkmg/WI11/HOMKMG-WI11-A5.pdf.

7. Istoriia banku [History of bank]. AT "PERSHYI INVESTYTSIINYI BANK" official web site. Retrieved from: https://www.pinbank.ua/pro-bank/bank-sogodni/bank-sogodni-2/.

8. Manders B. (2015). Implementation and Impact of ISO 9001. Doctor's thesis. Rotterdam: Erasmus University.

9. Pokaznyky bankivskoi systemy [Indicators of banking system] (2018). The National bank of Ukraine. bank.gov.ua. Retrieved from: https://bank.gov.ua/control/uk/publish/article?art_id=34661442\&cat_id=34798593.

10.Pres-tsentr [Press-center]. PAT "Credit Agricole bank" official web site. Retrieved from: https://creditagricole.ua/o-banke/pres-centr/novini/kredi-agrikol-bank-za-napryamom-avtomobilne-kredituvannya-ot-445.

11.Richnyi zvit AT "Ukreksimbank" 2013 [AT Ukreximbank annual report 2013]. AT "Ukreximbank" official web-site. Retrieved from: https://www.eximb.com/upload/app_links/2001.pdf.

12.Sharma, D. S. (2005). The Association between ISO 9000 Certification and Financial Performance. International Journal of Accounting, 40(2), 151-72.

13.Systema yakosti [System of quality]. PAT "KREDYTPROMBANK" official web site. Retrieved from: http://www.kreditprombank.com/ua/about/corp_managment/quality-control.

14.Terlaak, A., \& King, A. A. (2006). The Effect of Certifi cation with the ISO 9000 Quality Management Standard: A Signaling Approach. Journal of Economic Behavior and Organization, 60(4), 579-602.

15.Yahia-Berrouiguet, A., Mankouri, I., \& Benarbia, N. (2015). Impact of ISO 9001 Certification on Firm Performance: Case Study of Beni Saf Cement Company. Journal of Economics and Business Research, 1, 158-165. 